ORIGINAL ARTICLE

\title{
A new species of Coccoloba P. Browne (Polygonaceae) from the Brazilian Amazon with exceptionally large leaves
}

\author{
Efigenia de MELO ${ }^{1}$, Carlos Alberto CID FERREIRA², Rogério GRIBEL ${ }^{2 *}$ \\ Universidade Estadual de Feira de Santana, Dep. Ciências Biológicas, Av. Transnordestina s/n., Novo Horizonte, 44036-900, Feira de Santana, Bahia, Brazil \\ 2 Instituto Nacional de Pesquisas da Amazônia - INPA, Coordenação de Biodiversidade, Av. André Araújo, 2936, Petrópolis, 69.067-375, Manaus, Amazonas, Brazil \\ * Corresponding author: rogerio.gribel@inpa.gov.br; (D) https://orcid.org/0000-0002-0850-5578
}

\begin{abstract}
We describe and illustrate a new species of Coccoloba (Polygonaceae), named Coccoloba gigantifolia, from the Brazilian Amazon. It resembles Coccoloba mollis Casar, but differs from the latter species by its much larger leaves in the fertile branches. The species has only been recorded in the Madeira River basin, in the states of Amazonas and Rondônia, in the central and southwestern Brazilian Amazon. The description was based on herbarium material, cultivated plants, and individual trees in their natural habitat. We provide illustrations, photographs, and an identification key with morphological characteristics that distinguish the new taxon from the other two related taxa of the Coccoloba sect. Paniculatae, as well as comments on the geographic distribution and conservation status of the species.
\end{abstract}

KEYWORDS: taxonomic botany, Amazon rainforest, geographic plant distribution, Paniculatae

\section{Uma nova espécie de Coccoloba P. Browne (Polygonaceae) da Amazônia brasileira com folhas excepcionalmente grandes}

\section{RESUMO}

Uma nova espécie de Coccoloba (Polygonaceae) da Amazônia brasileira, denominada Coccoloba gigantifolia, é descrita e ilustrada. É semelhante a Coccoloba mollis Casar. mas difere desta espécie por ter folhas muito maiores nos ramos férteis. A espécie foi registrada apenas na bacia do Rio Madeira, nos estados do Amazonas e Rondônia, no centro e sudoeste da Amazônia Brasileira. A descrição foi feita a partir de material de herbário, plantas cultivadas e observações de campo de indivíduos em seu habitat natural. São apresentadas pranchas ilustrativas, fotografias e uma chave de identificação com caracteres morfológicos que distinguem o novo táxon de outras duas espécies de Coccoloba sect. Paniculatae, bem como, comentários sobre a distribuição geográfica e conservação da espécie.

PALAVRAS-CHAVE: botânica taxonômica, floresta amazônica, distribuição geográfica de plantas, Paniculatae

\section{INTRODUCTION}

The genus Coccoloba presents a neotropical distribution, and most of its species are only found in South America (Howard 1961). The number of species currently accepted for the genus is about 120 (Maas and Westra 1988), but this number has greatly varied over time owing to the paucity of sound taxonomic criteria. For instance, Howard (1960) listed 159 species of Coccoloba for South America, but later made a critical evaluation of the analyzed botanical materials and reduced the number of species to 77 in this region (Howard 1961). In Brazil, Coccoloba is the most representative genus of Polygonaceae with 45 accepted species (BFG 2015). Coccoloba species grow in humid habitats of the Amazon and Atlantic Forest biomes, but also in semiarid regions, seasonal savannas, and forests as well as on rupestrian fields (Melo 2004, Melo and França 2006).
Coccoloba species have tree-like, shrubby, or lianescent habit and exhibit articulated stems and branches. The leaves are alternate, with simple and entire blades, and smooth margin, similar to that present in all Polygonaceae. A remarkable characteristic of Coccoloba (in fact, of the whole Polygonaceae family) is the presence of an ochrea sheath, which is a structure at the base of the petiole that develops by the fusion of two stipules. This structure can be persistent or partially deciduous, and it usually leaves a scar around the petiole after it falls. Petioles are inserted in the ochrea base or a little above this structure and are articulated with it. The inflorescence is a thyrse with simple or ramified lateral branches. The species are polygamous-dioecious, and the functionally unisexual flowers are generally greenish-white. The perianth exhibits five-lobed, tepaloid segments, fused at 
the base, forming a small hypanthium without a distinction between the calyx and corolla. There are usually eight stamens, and the filaments commonly exhibit an enlarged, fused base, which forms a small ring adnate to the hypanthium. The androecium has three filiform styles with capitate or decurrent stigmas. The fruit is an anthocarp, named acrosarcum, which is characterized as a simple fruit with a fleshy perianth and a single seed adhered to the undifferentiated pericarp (Spjut 1994). The pericarp separated from the fruiting perianth is described as a nucule (Barroso et al. 1999).

In Coccoloba the plants are dioecious. The staminate flowers with large stamens have rudimentary pistils, and the pistillate flowers, with conspicuous pistils have small or rudimentary stamens (Howard 1960). Both flower types bear a disc-like nectar-producing structure formed by the expansion and fusion of the base of the stamens. This floral nectary surrounds the ovary and fills the entire cavity of the hypanthium. The development of the nectar structure varies among species (Melo et al. 2003).

Meisner (1855) described 51 species of Coccoloba for Flora Brasiliensis, which were split into two sections based on the inflorescence branching - Coccoloba sect. Racemosae, with 48 species, and Coccoloba sect. Paniculatae, with only two species. Twenty-three species were identified for the Brazilian Amazon, 21 in Coccoloba sect. Racemosae and two in C. sect. Paniculatae (Melo 2004). Species circumscription in Coccoloba is very confusing, with sharp contrasts among specialists, mainly because it is usually based on fragile and highly variable vegetative characteristics at an individual level (Howard 1960). This difficulty was apparent in the elaboration of floras (Ribeiro et al. 1999, Aymard and Howard 2004), where several species appear without identification. Here, we describe a new species from Coccoloba sect. Paniculatae based on morphological characteristics, and provide some information about its life history.

\section{MATERIAL AND METHODS}

The distribution map for the known occurrences of the new species was based on geo-referenced materials, both of photpgraphs of individuals in situ and of botanic samples collected by the authors and deposited at the herbarium of the Instituto Nacioal de Pesquisas da Amazônia - INPA (Manaus, Amazonas, Brasil) (Figure 1).

Samples with leaves up to $150 \mathrm{~cm}$ in length were dehydrated by the traditional drying techniques using drying ovens (Martins da Silva 2002). Due to the unfeasibility of accommodating leaves larger then $150 \mathrm{~cm}$ in length in drying ovens, samples of such large leaves were packed in specially constructed cardboard presses measuring $3 \times 1.70 \mathrm{~m}$ and were dehydrated using an air conditioner. After the completion of the drying process, some of the largest leaves $(>200 \mathrm{~cm}$ in length) were placed in wooden frames protected with glass for public exhibition at INPA and other institutions.

Morphological analysis and description were based on the samples in the INPA Herbarium, and from photographs and fresh material obtained from individuals cultivated at the INPA campus. Photographs of flowers and fruit details were made from fixed material using a stereoscopic binocular microscope Leica M205C coupled to a photographic camera Leica MC190HD.

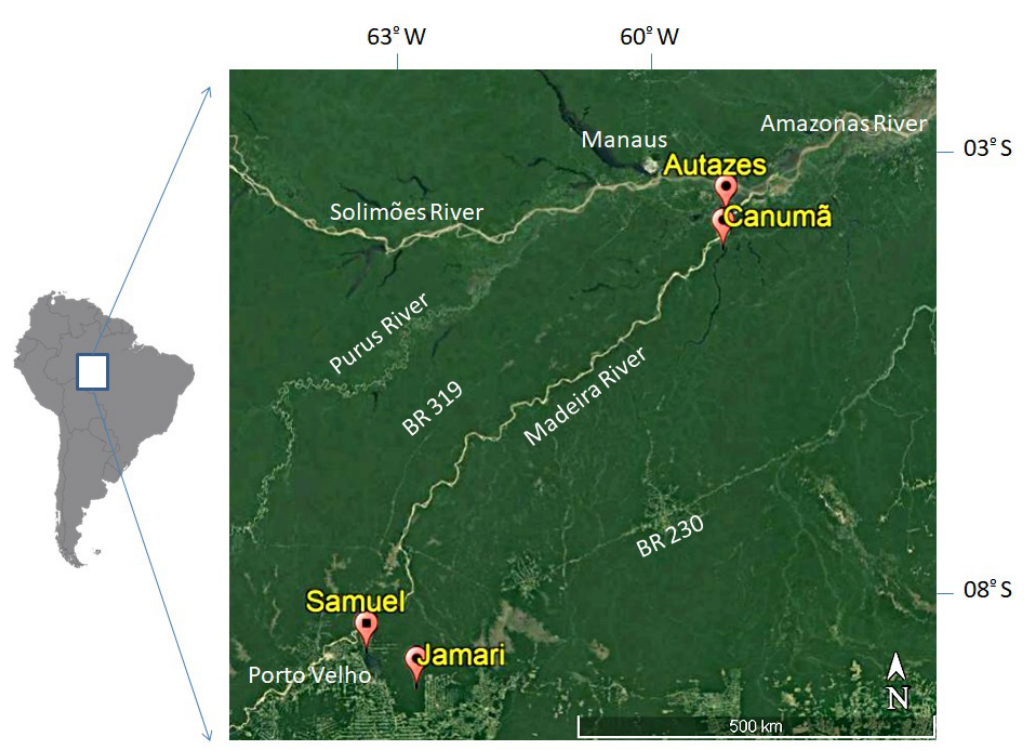

Figure 1. Location records of Coccoloba gigantifolia sp. nov. in the Madeira River basin, central and southwestern Brazilian Amazon. (Source: Google Earth). This figure is in color in the electronic version 


\section{RESULTS}

Coccoloba gigantifolia E. Melo, C.A. Cid Ferreira \& R. Gribel sp. nov. (Figures 1-3)

Type material: Brazil. Rondônia. Floresta Nacional do Jamari, Serra da Onça, $2 \mathrm{~km}$ from the residential village, $09^{\circ} 01^{\prime} \mathrm{S}$, 6302'W, 05.ix.2008 (fr.), C.A. Cid Ferreira et al. 11211 (Holotype: INPA 258.437).

Trees 10-15 $\mathrm{m}$ high, polygamous-dioecious, with a straight, segmented trunk that occasionally sprouts at the base with transverse rings distanced about $10 \mathrm{~cm}$, with thin branches of whitish bark restricted to the apex. The trees also have young, pubescent branches and ferruginous trichomes (Figures $2 \mathrm{a}-\mathrm{d}$ ). Leaves are alternate, spiral, and petiolate. Leaf blades measure $0.6-2.5 \times 0.5-1.4 \mathrm{~m}$ and are elliptic, with acute or acuminate apex, base obtuse, subcordate, subtruncate, entire margin, wavy, coriaceous or subcoriaceous, discolor, pubescent glabrescent, pubescent adaxial face with ferruginous trichomes concentrated in the veins when young, pubescent abaxial face with ferruginous trichomes, brochidodromous venation, 16-45 pairs of lateral veins, flat on the adaxial side and prominent on the abaxial face (Figure 2e); petiole is $5-10 \mathrm{~cm}$ long, inserted at the base of the ochrea and articulated to it (Figure 2f), older leaves are completely glabrous or puberule; ochrea is $5-10 \mathrm{~cm}$ long, persistent at base, coriaceous, pubescent ferruginous, apex with acuminate edge, scariose and deciduous. Inflorescence a branched thyrse, paniculate, $40-80 \mathrm{~cm}$ in length (Figure $2 \mathrm{~g}$ ), rachis pubescent or puberulent, glabrescent, triangular bracts, $0.2-0.3 \mathrm{~mm}$, coriaceous, puberulent or pubescent; ochreola campanulate, 0.5-10 mm, membranaceous, puberulent or pubescent with bilobed edge, persistent and lacerated after fruit maturation (Figure 3a). Flowers 1-2 mm in length, greenish-white; staminate flowers with campanulate hypanthium and vestigial pistil, stamens excluded, filaments fused at the base to form a bulbous, nectariferous tissue, covered with whitish papillae (Figure 3b), pistillate flowers with campanulate hypanthium, reduced stamens, reduced and sterile anthers, ovary ovoid, three glabrous styles, stigmas capitate papillose. Anthocarps 5-8 mm long, globose (Figure 3c-d), pubescent or puberulent, red, vinaceous or purple when mature (Figure $2 \mathrm{~h}-\mathrm{i})$; globose nucules, smooth, slightly grooved, apex acute or pyramidal (Figure 3e), seeds with ruminate endosperm (Figure 3f); fruit pedicels $2-5 \mathrm{~mm}$ long, not thickened.

Material examined: Brazil. Amazonas, Manaus, cultivated at the INPA campus V8, 27.v.2014 (fr), C.A. Cid Ferreira 13284 (INPA); Iden, 10.vi.2017 (fr), C.A. Cid Ferreira 13285 (INPA); Iden, 08.iii.2018 (bt., fl.) C.A. Cid Ferreira 13286 (INPA); Iden, 20.vi.2018, (f) C.A. Cid Ferreira 13287 (INPA). Rondônia, Jamari National Forest, 28.ix.1993 (sterile), C.A. Cid Ferreira et al. 11150 (INPA); Jamari, Serra da Onça, $2 \mathrm{~km}$ from the residential village, $09^{\circ} 01^{\prime} \mathrm{S}$,

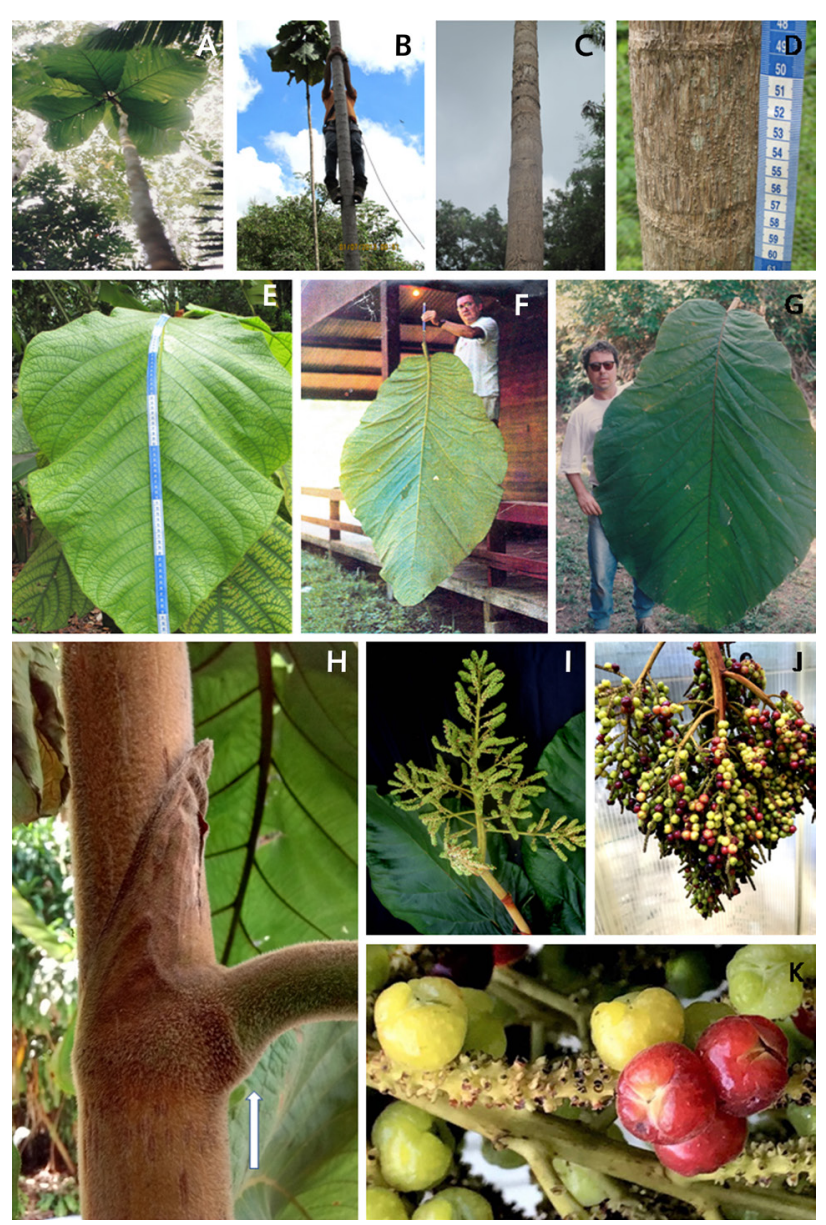

Figure 2. A. Individual of Coccoloba gigantifolia about $15 \mathrm{~m}$ high in its natural environment, reaching the sub-canopy of a secondary forest in the Jamarí National Forest (Rondônia state, Brazil); B. Individual in the collection process; C. Trunk of a cultivated adult plant; D. Details of the trunk showing two transverse rings; $E$. Leaf of a young cultivated plant; F. Leaf sample collected in the Jamari National Forest (Rondônia state, Brazil), $2.15 \mathrm{~m}$ long and $1.38 \mathrm{~m}$ wide (abaxial view); $\mathrm{G}$. Adaxial view of the same leaf; $H$. View of the petiole articulation at ochrea base in a young branch; I. Inflorescence; J-K. Mature fruits (Credits: A-G and I-K: C.A. Cid Ferreira and R. Gribel, H: E. Melo). This figure is in color in the electronic version

6302'W, 05.ix.2008 (fr.), C.A. Cid Ferreira et al. 11211 (holotype: INPA), Porto Velho, Jirau hydroelectric dam, BR364, $09^{\circ} 15^{\prime}$ S, 64º21'W, 28.iii.2011, (f.), M.F. Simon et al. 1237 (CEN, HUEFS, INPA, RON).

\section{Record history of Coccoloba gigantifolia}

The plant was first observated in 1982 at the Canumã River (approximate coordinates: $04^{\circ} 12^{\prime} \mathrm{S}$; $59^{\circ} 16^{\prime} \mathrm{W}$ ), a tributary of the Madeira River, in the municipality of Borba (Amazonas State) during an expedition of the "Projeto Flora Amazônica" (INPA and the New York Botanical Garden), when a largeleaved (> $1.5 \mathrm{~m}$ blade length), sterile individual of Coccoloba was recorded by the botanical team. Due to the lack of fertile parts, no specimen was collected (C. A. Cid Ferreira, personal 


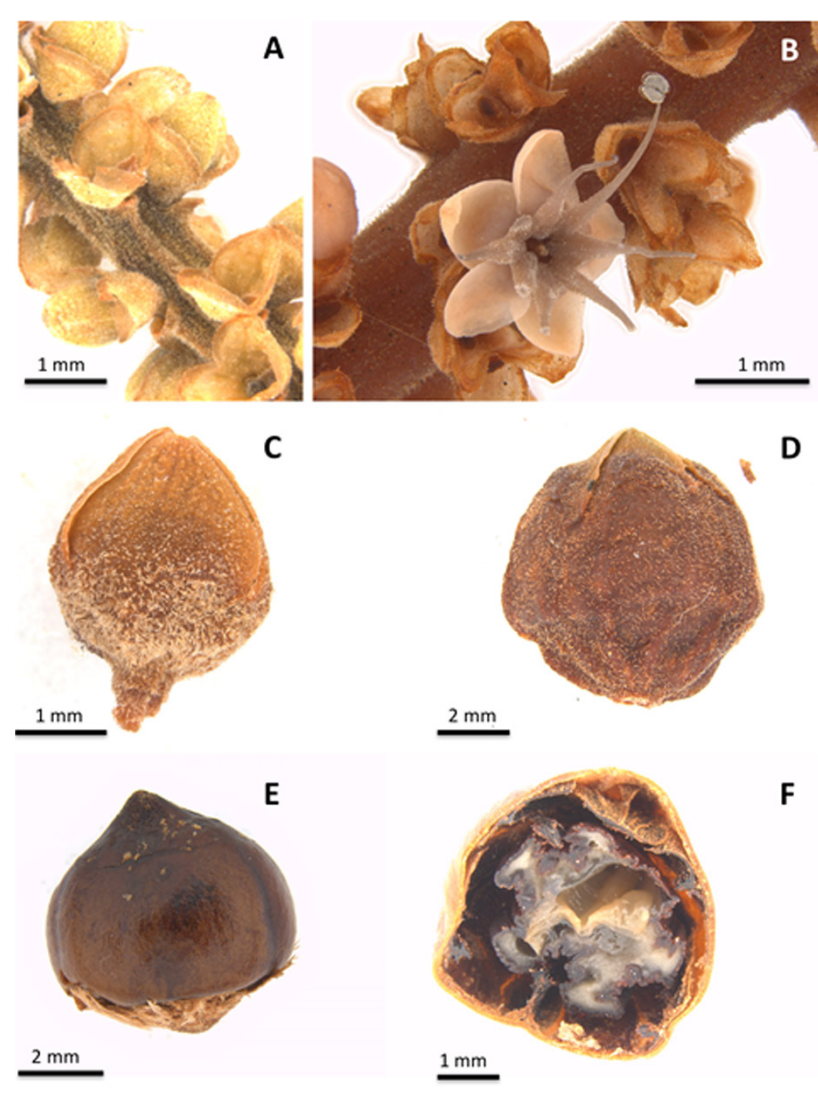

Figure 3. A. Inflorescence of Coccoloba gigantifolia showing persistent bracts and ochreolas; B. Details of the staminate flower showing the nectaries at the base of the filaments; C. Dehydrated immature fruit; D. Dehydrated mature fruit; E. Nucula after the removal of the perianth; F. Transverse section of the nucula showing the ruminate endosperm (Credits: D. L Komura). This figure is in color in the electronic version

observation). In 1986, an expedition of INPA's Botany Department led by the botanist Juan Revilla found and made a photographic record of a very large-leaved, sterile individual of Coccoloba in the influence area of the Samuel hydroelectric dam (08 $46^{\prime}$ S; 63⒉ 'W), near Porto Velho city, in the state of Rondônia (Supplementary Material, Figure S1), but, again, no herbarium samples were collected.

During expeditions to the Jamarí National Forest between 1989 and 1993, 14 individuals of the large-leaved Coccoloba were found by C.A. Cid Ferreira, R. Gribel, and Jaime Tadeu França in the localities of Serra da Onça and Igarapé do Leite (approximate coordinates: $09^{\circ} 01^{\prime} S ; 63^{\circ} 02^{\prime} \mathrm{W}$ ). Although the individuals were sterile, some large leaves were collected and deposited in the INPA Herbarium. In 1995, individuals of large-leaved Coccoloba were photographed by Sivestre Silva [photos in Silva and Leão (2006); Supplementary Material, Figure S1] at a vicinal road (Rosarinho road) connecting the city of Autazes to the left bank of the Madeira River, about $110 \mathrm{~km}$ southeast of Manaus (approximate coordinates: 0339'S, 5906'W). In August 2005, an expedition to another area in the vicinity of the Jamari National Forest (approximate coordinates: $09^{\circ} 15^{\prime} \mathrm{S}, 64^{\circ} 21^{\prime} \mathrm{W}$ ) finally enabled the collection of fertile samples (inflorescences) by C. A. Cid Ferreira and R. Gribel for the INPA Herbarium. Mature fruits and seeds beneath one individual tree were also collected. These seeds were propagated at INPA by Sidney Ferreira, originating all the trees of C. gigantifolia planted in the Manaus region (within and outside INPA campi) since then. All fertile materials deposited at INPA Herbarium from 2008 to the present come from the individuals cultivated in Manaus, that originated from seeds of an individual of the Jamari River region.

\section{Geographic distribution and habitat}

Coccoloba gigantifolia is endemic to the Madeira River basin. So far, individuals have been recorded in the states of Amazonas and Rondônia (Figure 1). At present, individuals have been collected in the wild only in the middle (Jamari and Samuel) and lower (Autazes and Borba) stretches of the Madeira River basin. The distance between the sampled populations of the middle and low Madeira River is of approximately $600 \mathrm{~km}$, which may indicate a disjunct distribution restricted to the Madeira River basin. The scarcity of botanical collections in the region, however, does not allow to draw reliable conclusions about the distribution of the species. Coccoloba gigantifolia grows in open, ombrophylous forests, secondary forests, and in early successional stages (capoeira, in Portuguese), in altitudes of 20-100 m a.s.l., in areas of flat relief, on sandy or clayey, humid soils. Cultivated trees in Manaus bloomed from March to June and exhibited mature fruits in September.

\section{Etymology}

The specific epithet of $C$. gigantifolia is given in reference to its leaves presenting unusual proportions.

\section{Key to species of Coccoloba sect. Paniculatae}

1. Leaves 0.6-2.5 x 0.5-1.44 m long. Campanulate ochreola with bilobed margin. Pistillate flowers with campanulate hypanthium. Globose fruiting perianth, globose nucule slightly grooved, with acute or pyramidal apex .... Coccoloba gigantifolia

1'. Leaves less than $0.60 \mathrm{~m}$ long 2

2. Cylindrical ochreola, with bilobed margin. Pistillate flowers with tubular hypanthium. Ovoid nucule non-grooved, with obtuse apex ..................................... Coccoloba mollis

2'. Campanulate ochreola with truncated margin. Pistillate flowers with campanulate hypanthium. Ovoid or globose nucule, grooved, with obtuse apex ........ Coccoloba latifolia

\section{DISCUSSION}

\section{Main diagnostic characteristics}

Coccoloba gigantifolia is an outstanding species due to its vegetative size, with a straight non-branching trunk, and very 
large apical leaves. In this aspect, the new species resembles Coccoloba pubescens, a plant native to the Caribbean and West Indies, which does not occur in Brazil. In addition, C. pubescens presents orbicular leaves with a cordate or subcordate base that reaches $90 \mathrm{~cm}$ in diameter and a very long and erect petiole (Little Jr. and Wadsworth 1964). Coccoloba gigantifolia, as well as C. pubescens, has a straight trunk, without ramifications or with ramifications restricted to the apex. However, C. pubescens produces flowers in long inflorescences of racemiform thyrsus, up to $60 \mathrm{~cm}$ in length (Litle Jr. and Wadsworth 1964).

Coccoloba gigantifolia belongs to the small group of Coccoloba sect. Paniculatae (Meisner 1855), which includes C. mollis Casar. and C. latifolia Lam., both occurring in the Brazilian Amazon. Coccoloba dugandiana Fernández was described for Bolivia and recognized as a valid species by Aymard and Howard (2004), but has since then been considered as synonymous of C. mollis (Melo 2004, The Plant List 2010).

Coccoloba gigantifolia is distinguished from C. mollis by presenting much larger leaves (usually $0.6-2.5 \mathrm{~m}$ long, with $20-45$ pairs of lateral veins), ochreas with $5-10 \mathrm{~cm}$ length, inflorescences $40-80 \mathrm{~cm}$ long, campanulate ochreolas larger than bracts, flowers with campanulate hypanthium, globose fruiting perianth, globose nucule, slightly grooved, with apex acute pyramidal, while $C$. mollis presents smaller leaves (8-40 cm long, 8-16 pairs of lateral veins), ochreas with $2-4 \mathrm{~cm}$ length, inflorescences $20-30 \mathrm{~cm}$ long, bracts and ochreola of the same size, cylindrical ochreola, pistillate flowers with tubular hypanthium, ovoid fruiting perianth, and ovoid nucule with obtuse apex, but not grooved. Coccoloba gigantifolia is distinguished from C. latifolia by presenting general pubescence in the branches, ochreas, leaves, inflorescences, and fruiting perianth, while C. latifolia is completely glabrous.

It is noticeable that, in Coccoloba species, much larger leaves can be formed in the branches sprouting at the base of the trunk, especially in the plants that have been traumatized or cut, whereas the leaves of the fertile branches tend to be smaller (Melo 2003). Among the species with paniculate inflorescences, C. mollis and C. latifolia may have leaves up to 30-50-cm long in young branches and also in branches in which the main stem was cut. This condition has also been recorded in C. pubescens (Little Jr. and Wadsworth 1964). In C. gigantifolia, contrary to what has been recorded in other species, leaves smaller than $50 \mathrm{~cm}$ in length were not observed and the leaves of the basal and apical branches differ little in size.

Coccoloba gigantifolia, therefore, can be easily recognized in the field, even if sterile. In addition to the large leaves, the main characteristics that distinguish this species from its congeners are: (a) the straight trunk with transverse rings, (b) leaves with articulated petiole inserted in the base of the ochrea, (c) the general pubescence, and (d) the presence of a hollow medulla in the branches. The leaf vein pattern is of the brochydodromous type (cf. Hickey, 1974), as it is already registered for the leaves of other Coccoloba species (Melo 2003).

The flowers of the new species are very similar to those of all other species of already described Coccoloba. It has already been recorded by Howard (1960) that Coccoloba flowers are highly homogeneous and do not present a great taxonomic value in the distinction of species. The presence of a welldeveloped nectary-like structure in staminate flowers confirms what has already been described in other Coccoloba species (Melo et al.2003). On the other hand, the presence of papillae coating the nectary-like structure is uncommon and had not yet been observed in Coccoloba species.

\section{Conservation status and further research}

Coccoloba gigantifolia seems to be a relatively rare species, with its presence restricted to the Madeira River basin. Additionally, its distribution may be disjunct from the lower to the middle Madeira River basin, up to the region of the Jamarí River. The biodiversity of the middle Madeira region has been impacted by infrastructure development projects, such as the Santo Antônio, Jirau, and Jamari hydroelectric dams, as well as the expansion of the agricultural frontier (soy monoculture and pastures) in the states of Rondônia, northern Mato Grosso, and southern Amazonas. Government plans to pave the BR 319 highway (from Manaus to Porto Velho), along the left margin of the Madeira River (Figure 1), also pose a threat to the region's natural environments. It is very likely that the small and possibly disjunct wild populations of $C$. gigantifolia will be strongly threatened in the near future by fire and deforestation caused by the advancement of agriculture and road infrastructure. Based on this scenario, we suggest that the species should be classified as "Endangered", which includes the taxa with a high risk of extinction in nature according to the IUCN criteria established in the Red Book of Flora do Brazil (Martinelli and Moraes 2013).

Because of its gigantic leaves and unusual appearance, this species should be the subject of further studies aimed at understanding its biology and conservation status. As it is a species with obvious economic potential as an ornamental tree, it is important to study aspects of its reproductive biology, requirements for propagation, growth rate, and associations with other organisms.

\section{CONCLUSIONS}

We describe a new species of Coccoloba (Polygonaceae), named Coccoloba gigantifolia from the Madeira River basin, in the Brazilian Amazon region. The species is very distinct, mainly due to the large size of the leaf blade, and is further 
differentiated by the petiole inserted at the base of the ochrea and articulated to it, inflorescence in panicles, campanulate ochreola with bilobate border, globose anthocarps and globose nucules, slightly grooved with an acute or pyramidal apex.

\section{ACKNOWLEDGMENTS}

Special thanks to Jaime Tadeu França (Instituto Brasileiro do Meio Ambiente e dos Recursos Naturais Renováveis IBAMA-DF) for informing us about the location of several individuals of $C$. gigantifolia in the Jamari National Forest and for assistance in the field. To Silvestre Silva and Juan Revilla, who kindly provided photos of $C$. gigantifolia individuals found by them in the field. To the curator of the INPA Herbarium, Mike Hopkins, for the support during the herbarium work and the warm welcome. To all collectors and field assistants, for their careful work to collect and prepare the large $C$. gigantifolia leaves. To Dirce Komura for the support with the microphotographies. To Nori Erazo for the assistance and attention during the work at INPA. To Flávio França for corrections and suggestions on the manuscript.

\section{REFERENCES}

Aymard, G.A.; Howard, R.A. 2004. Polygonaceae. In: Berry, P. E. et al. (Eds.) Flora of the Venezuelan Guayana, 8: 347-370.

Barroso, G.M.; Morim, M.P.; Peixoto, A.L.; Ichaso, C.L.F. 1999. Fruits and seeds: morphology applied to dicotyledonous systematics. Universidade Federal de Viçosa, Brazil, 443p.

BFG. 2015. The Brazil Flora Group. Growing knowledge: an overview of seed plant diversity in Brazil. Rodriguesia, 66: 1085-1113.

Hickey, L.J. 1974. Classification de la arquitectura de las hojas de dicotiledoneas. Boletín de la Sociedad Argentina de Botánica, 26: $1-25$.

Howard R.A. 1960. Studies in the Genus Coccoloba, IX. A critique of the South American species. Journal of the Arnold Arboretum, 41: 213-390.

Howard, R.A. 1961. Studies in the Genus Coccoloba, X. New species and a summary of distribution in South America. Journal of the Arnold Arboretum, 42: 87-95.
Little Jr., E.L; Wadsworth, F.H. 1964 . Common Trees of Puerto Rico and the Virgin Islands. Agriculture Handbook 249, USDA Forest Service, Washington, 548p.

Maas, P.J.M.; Westra, L.Y. 1998. Neotropical plant families. Editora A.R.G. Gantner, Germany, 315p.

Martinelli, G.; Moraes, M.A. 2013. Livro Vermelho da Flora do Brasil. Instituto de Pesquisas do Jardim Botânico do Rio de Janeiro and Andrea Jakobson, Rio de Janeiro, 1100p.

Martins da Silva, R.C.V. 2002. Coleta e identificação de espécimes botânicos. Embrapa Amazônia Oriental, Belém, Documento 143, p. $1-40$..

Meisner, C.F. 1855. Polygonaceae. In: Martius, C.F.P. and Eichler, A.W. (Ed.). Flora Brasiliensis. Typographia Regia, Monachii, p.1-59.

Melo, E.; Leite, K.R.B.; França, F.; Giulietti, A.M. 2003. Morphoanatomy of staminate and pistillate flowers of Coccoloba species P. Browne (Polygonaceae). Iheringia Série Botânica, 58: 215-226.

Melo, E. 2003. Review of species of the genus Coccoloba P. Browne nom. cons. (Polygonaceae) from Brazil. Doctoral thesis. Universidade de São Paulo, Brazil. 418p.

Melo, E. 2004. The species of Coccoloba P. Browne (Polygonaceae) from the Brazilian Amazon. Acta Amazonica, 34: 525-551.

Melo, E.; França, F. 2006. The family Polygonaceae in the Brazilian semiarid. In: Giulietti, A.M. et al. (Ed.). Diversity and characterization of Brazilian semiarid phanerogams. Associação Plantas do Nordeste, Recife, p.437-488.

Silva, S.; Leão, N.V.M. 2006. Árvores da Amazônia. Empresa das Artes, São Paulo, 243p.

Souza, M.A.D.; Brito, J.M. 1999. Polygonaceae. In: Ribeiro, J.E.L.S; Hopkins, M.J.G.; Vicentini, A.; Sothers, C.A.; Costa, M.A.S.; Brito, J. M. et al. (Ed.). Flora of the Ducke Reserve: identification guide of vascular plants of a terra firme forest in Central Amazonia. Editora INPA, Manaus. 816p.

Spjut, R.W. 1994. A systematic treatment of fruit types. Memoirs of the New York Botanical Garden, 70: 1-182.

The Plant List. 2010. Version 1. The Plant List. (www.theplantlist. org). Accessed on 1st Jan 2019.

RECEIVED: 07/02/2019

ACCEPTED: 02/07/2019

ASSOCIATE EDITOR: Natália Ivanauskas 
ACTA

AMAZONICA

MELO et al. A new species of Coccoloba from the Brazilian Amazon

SUPPLEMENTARY MATERIAL (only available in the electronic version)

MELO et al. A new species of Coccoloba P. Browne (Polygonaceae) from the Brazilian Amazon with exceptionally large leaves
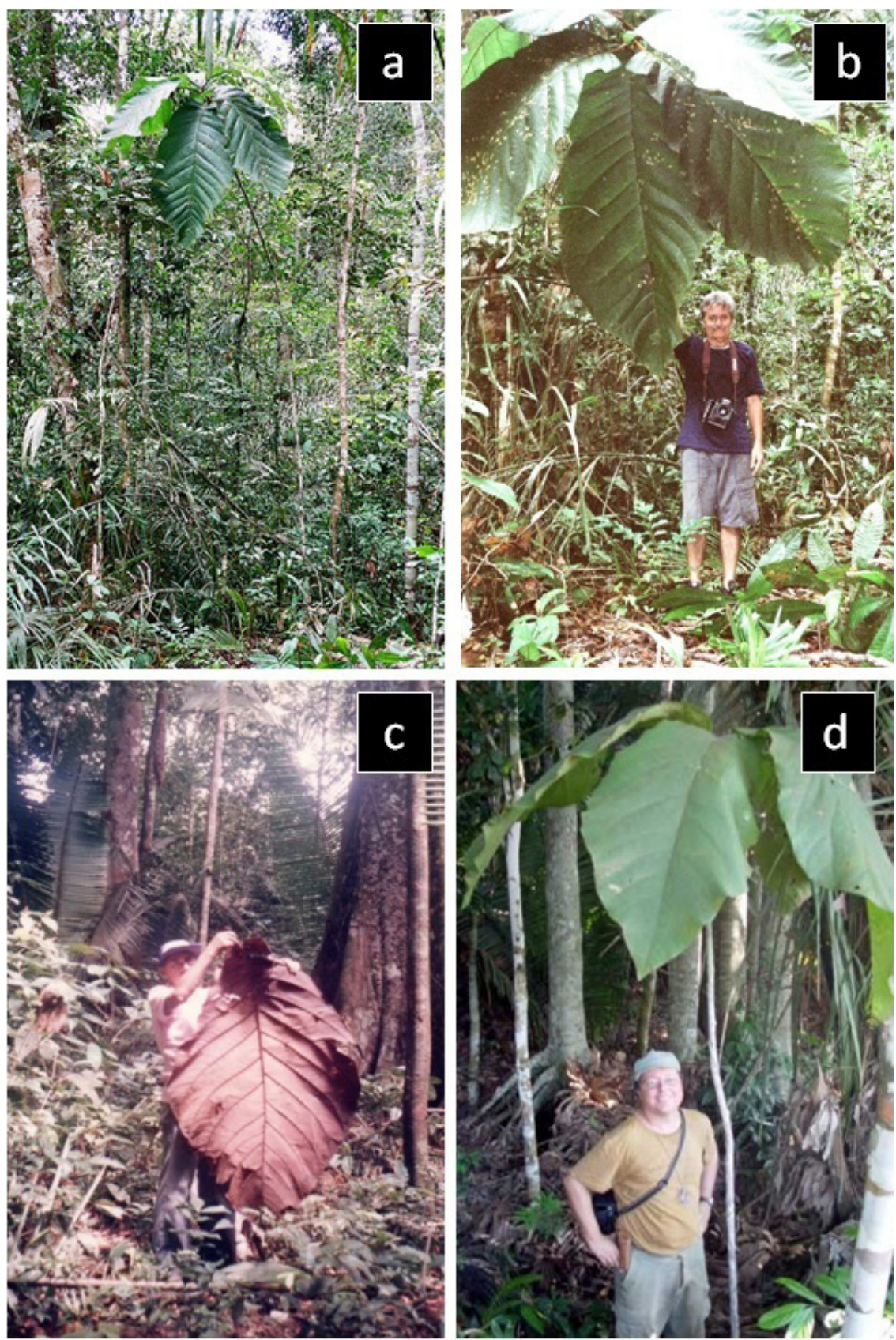

Figure S1. Individuals of Coccoloba gigantifolia photographed in its natural occurrence sites. A and B. Brazil, Amazonas State, Autazes, 110 km southeast of Manaus, 0339'S, 5906'W, 1995, sterile (credit: Silvestre Silva); C. Brazil, Rondônia State, Candeias do Jamarí, Samuel hydroelectric dam area, 56 km east of Porto Velho, Samuel

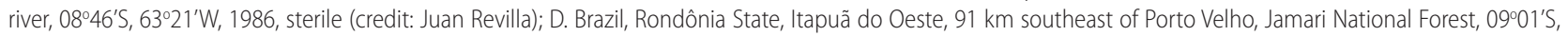
$63^{\circ} 02^{\prime}$ W, 2003, sterile (credit: Rogério Gribel). 